Fifth International Conference on Sustainable Construction Materials and Technologies. http://www.claisse.info/Proceedings.htm

$5^{\text {th }}$ International conference on sustainable construction materials and technologies

RILEM session

\title{
EFFECT OF QUICK FIRING ON THE HYGRO- MECHANICAL BEHAVIOUR OF EARTH BRICKS
}

\author{
Céline Perlot ${ }^{1}$, Domenico Gallipoli ${ }^{1}$, Agostino Walter Bruno ${ }^{2}$ \\ ${ }^{1}$ Université de Pau et des Pays de l'Adour / E2S UPPA, Laboratoire des \\ Sciences de l'Ingénieur Appliquées \\ écanique et au Génie Electrique - IPRA, EA4581, 64600, Anglet, France. \\ ${ }^{2}$ School of Engineering, Geotechnics and Structures, Newcastle University, \\ United Kingdom
}

\begin{abstract}
This paper presents the effect of quick firing on the compressive strength and moisture adsorption capacity of earth bricks manufactured according to three differentmethods, i.e. extrusion, standard Proctorcompaction and hypercompaction to $100 \mathrm{MPa}$. All bricks were fired inside an electrical furnace by rising the temperature at a quick rate of about $9^{\circ} \mathrm{C}$ per minute to $280,455,640,825$ and $1000{ }^{\circ} \mathrm{C}$, after which the furnace was turned off and left to cool to the atmosphere with the brick inside it. Results show that quick firing of hypercompacted bricks at moderate temperatures, between 455 and $640{ }^{\circ} \mathrm{C}$, is enough to attain very high levels of compressive strength, between 29 and $34 \mathrm{MPa}$, and a good moisture adsorption capacity. The strength of hypercompacted bricks further increases to $53 \mathrm{MPa}$, a value similar to that of high-strength concrete, after quick firing at $825^{\circ} \mathrm{C}$. Hence, the combination of hypercompaction and quick firing improves material performance while enabling a significant reduction of firing temperatures and times compared to current bricks production methods.
\end{abstract}

Keywords: Bricks production; firing treatment; porosity; compressive strength; moisture buffering capacity.

\section{INTRODUCTION}

Raw (i.e. unfired) earth bricks are manufactured with low embodied energy (Little and Morton, 2001; Morel et al., 2001) and exhibit, during service life, a strong tendency to exchange water vapour with the environment depending on the indoor humidity. This property increases hygro-thermal inertia and helps smoothing daily fluctuations of humidity and temperature inside buildings with a consequent improvement of occupant comfort and an associated reduction of air conditioning needs (Houben and Guillaud, 1989; Allinson and Hall, 2010; Pacheco-Torgal and 
Jalali, 2012; Soudani et al., 2016; Gallipoli et al., 2017; Soudani et al., 2017). However, raw earth is still disregarded in mainstream construction due to the low levels of water durability and strength. Chemical stabilisers such as cement or lime are often added to the earth to improve mechanical characteristics (Walker and Stace, 1997; Guettala et al., 2006; Jayasinghe and Kamaladasa, 2007; Kariyawasam and Jayasinghe, 2016; Venkatarama Reddy et al., 2016; Dao et al., 2018).

Unfortunately, the addition of chemical stabilisers reduces the moisture buffering capacity and hygro-thermalinertia of the material (Liuzzi et al., 2013; McGregor et al., 2014; Arrigoni et al., 2017) while largely increasing the carbon footprint (Worrell et al., 2001). Alternative stabilisation methods are therefore necessary to improve the material performance with a reduced environmental impact. In this respect, the application of moderate heat as a possible stabilisation method has been considered only by a handful of studies (e.g. Mbumbia et al., 2000; Karaman et al., 2006). These studies concluded that temperature plays a key role in changing the physical and mechanical properties of the bricks while firing time has little effect.

The present work investigates the effect of quick firing at relatively low temperatures on the hygro-mechanical behaviour of earth bricks manufactured by extrusion, standard Proctorcompaction and hypercompaction. Quick firing is accomplished by placing a raw earth brick inside an electrical furnace and rapidly increasing the temperature to a given target, after which the furnace is switched off and allowed to cool to the atmosphere with the brick inside it. For hypercompacted bricks, a moderate temperature, between $455{ }^{\circ} \mathrm{C}$ and $640{ }^{\circ} \mathrm{C}$, is sufficient to generate a compressive strength of about $30 \mathrm{MPa}$ and a good to excellent moisture buffering capacity. Remarkably, hypercompacted bricks quickly fired at the higher temperature of $825{ }^{\circ} \mathrm{C}$ exhibit a compressive strength of $53 \mathrm{MPa}$. The results obtained in the present work therefore indicate that a less energy-intensive thermo-mechanical process can be devised to improve production of earth bricks while reducing environmental impact and increase efficiency. These preliminary results must however be supported by further investigation to quantify the ensuing energy savings and to extend the characterization of the hygromechanical and durability characteristics of the produced bricks.

\section{MATERIAL AND METHODS}

The earth used in the present work has been provided by the brickwork factory NAGEN from the region of Toulouse (South-West of France). The grain size distribution was determined by both wet sieving and sedimentation in compliance with the norms XP P94-041 (AFNOR, 1995) and NF P 94-057 (AFNOR,1992), respectively, which indicate that the material is composed by $40.8 \%$ sand, $42.9 \%$ silt and $16.3 \%$ illitic clay. The Atterberg limits of the fine fraction (i.e. the soil fraction smaller than $400 \mu \mathrm{m}$ ) were determined according to the norm NF P94-051 (AFNOR, 1993), which indicates a liquid limit of $33.0 \%$ and a plasticity index of $12.9 \%$. Both grain size distribution and plasticity properties also satisfy existing recommendations for compressed earth bricks (e.g. MOPT, 1992; Houben and Guillad, 1994; CRATerre-EAG, 1998; AFNOR, 2001) as discussed by Bruno et al. (2017). 
Raw earth bricks were then manufactured according to three different methods, namely extrusion, standard Proctor compaction and hypercompaction. Both Proctor compacted and hypercompacted bricks haddimensions of $200 \times 100 \times 50 \mathrm{~mm}^{3}$, while extruded bricks had slightly larger dimensions of $220 \times 110 \times 50 \mathrm{~mm}^{3}$. This small variation was the consequence of the different sizes of the screw press ejector of the extruded bricks and the compaction mould of Proctor and hypercompacted bricks. A brief description of the three manufacturing processes is given below:

- Extrusion. Extruded bricks were manufactured by the brickwork factory NAGEN according to the same process used for standard fired bricks. The dry earth was passed through a grinder and sieved to remove grains larger than $1 \mathrm{~mm}$. The sieved earth was subsequently mixed with an optimum water content of about $18 \%$ and conveyed to a screw extruder with a rectangular ejector section of $110 \times 50 \mathrm{~mm}^{2}$. Finally, the extruded strip was cut into individual bricks with length of $220 \mathrm{~mm}$.

- Standard Proctor compaction. The dry earth was mixed at the optimum water content of $13.5 \%$, which had been previously determined by standard Proctor compaction of samples at different water contents (AFNOR, 1999). The moist earth was subsequently placed inside a stiff rectangular mould and statically compacted with a displacement rate of $0.1 \mathrm{~mm} / \mathrm{s}$ to attain a dry density of $1860 \mathrm{~kg} / \mathrm{m}^{3}$, which corresponds to the Proctor optimum.

- Hypercompaction. The dry earth was mixed at the optimum water content of $5.2 \%$, which had been previously determined by static compaction to $100 \mathrm{MPa}$ of samples at different water contents (Bruno, 2016). The moist earth was then compacted to $100 \mathrm{MPa}$ with a rate of $0.17 \mathrm{MPa} / \mathrm{s}$, which resulted in a very dense material with an average porosity of 0.13 . Further details about the hypercompaction procedure can be found in Bruno (2016).

After manufacturing, all bricks were equalised to the laboratory atmosphere, corresponding to a temperature of about $25{ }^{\circ} \mathrm{C}$ and a relative humidity of about $40 \%$, for a minimum of one week and until a constant mass was attained. After equalisation, a set of bricks was kept inside the laboratory while another set was prepared for the subsequent firing stage by drying for 24 hours at $105{ }^{\circ} \mathrm{C}$ followed by 12 hours at $200{ }^{\circ} \mathrm{C}$. Bricks were then fired inside an electrical furnace at five different temperatures of $280,455,640,825$ and $1000{ }^{\circ} \mathrm{C}$. In all cases, the temperature was increased with an approximately constant rate of $9{ }^{\circ} \mathrm{C}$ per minute, which was the fastest rate allowed by the furnace. Once the target temperature was reached, the furnace was turned off and left to cool overnight with the brick inside it. After firing, bricks were again equalised to the laboratory atmosphere (temperature of $25{ }^{\circ} \mathrm{C}$ and relative humidity of $40 \%$ ) until a constant mass was recorded and, in any case, for not less than two weeks. Quickly fired bricks were then tested to measure compressive strength and moisture adsorption capacity. 


\section{RESULTS AND DISCUSSION}

\section{Compressive Strength Test Results}

Compressive strength tests were conducted by using a displacement-controlled Zwick/Roell Amsler HB250 press with a capacity of $250 \mathrm{kN}$. Bricks were loaded along the longest dimension with a constant displacement rate of $0.001 \mathrm{~mm} / \mathrm{s}$. End-friction confinement was reduced by applying Teflon spray on the top and bottom press plates before placing them in contact with the brick extremities and starting the test. Note that the temperature of $25{ }^{\circ} \mathrm{C}$ refers to the unfired bricks, which were only equalised to the laboratory atmosphere without any thermal treatment.

Figure 1 shows that hypercompacted bricks exhibit significantly higher compressive strength than Proctor compacted and extruded bricks at all firing temperatures, which is consistent with their greater density. Forhypercompacted bricks, quick firing at a relatively low temperature of $455^{\circ} \mathrm{C}$ is already enough to attain a very high strength of $29 \mathrm{MPa}$, which is better than current recommendations for masonry buildings exposed to severe weathering (ASTM C62-13a, 2013). The strength of hypercompacted bricks increases even further to $53 \mathrm{MPa}$, a value typical of top performing materials such as high-strength concretes, after quick firing at $825{ }^{\circ} \mathrm{C}$. Inspection of Figure 1 also indicates that, regardless of the manufacturing method, strength increases as firing temperature rises from $25^{\circ} \mathrm{C}$ to $825^{\circ} \mathrm{C}$ but then decreases as temperature further grows to $1000{ }^{\circ} \mathrm{C}$.

This can be due to the almost simultaneous occurrence, at temperatures above $550{ }^{\circ} \mathrm{C}$, of carbonaceous organics burn off and mineral dihydroxylation with the consequent bonding of alumina and silica particles that augments material strength (West and Gray, 1958). This increase of strength is however counteracted by a second mechanism, which is typical of quick firing and consists in the rapid vitrification of the brick surface impeding evacuation of carbon dioxide and water vapour from the inner material. This promotes the formation of large pores with a consequent reduction of density and strength at higher temperatures (Karaman et al., 2006; Baccour et al., 2009). Finally, an increase in temperature above $950{ }^{\circ} \mathrm{C}$ induces the transformation of illite into less stable spinel (MgOAl2O3) and hercynite (FeOAl2O3) (Jordan et al., 1999 and Aras, 2004), which also contributes to the drop of strength at $1000{ }^{\circ} \mathrm{C}$. 


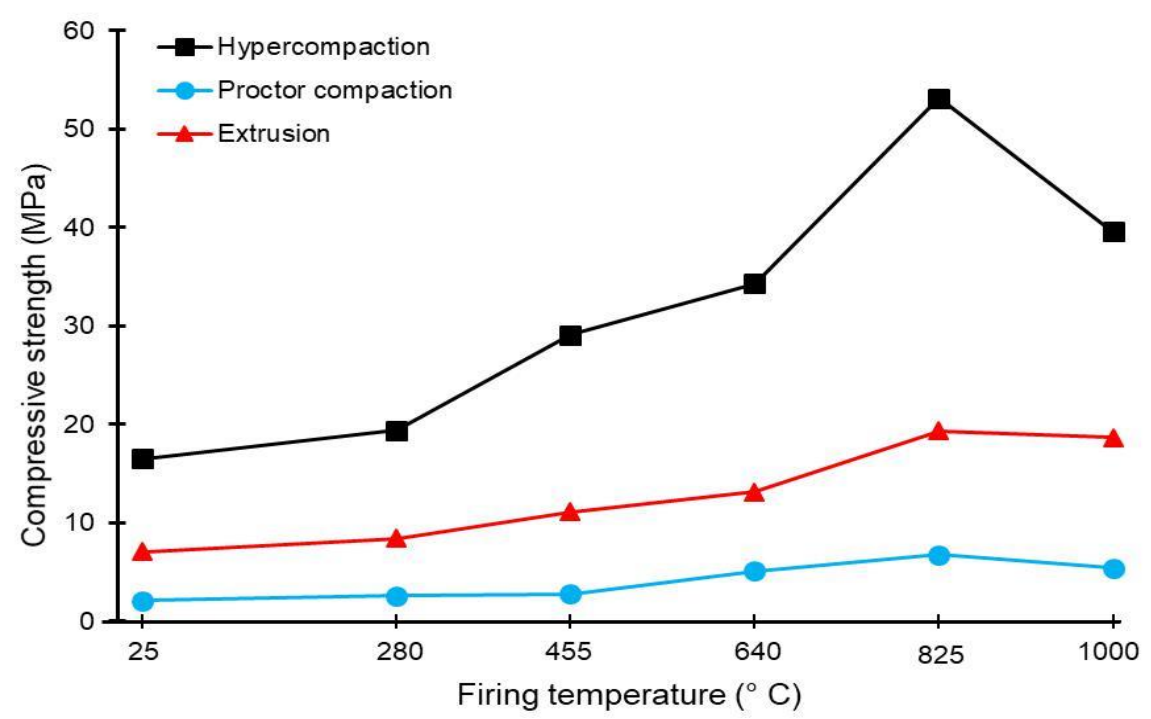

Figure 1. Compressive strength of unfired $\left(25^{\circ} \mathrm{C}\right)$ and quickly fired $(280,455,640$, $\left.825,1000{ }^{\circ} \mathrm{C}\right)$ bricks.

\section{Moisture Buffering Capacity Test Results}

A last set of tests was performed to investigate the moisture adsorption capacity of the bricks according the norm ISO 24353 (2008). These tests consisted in exposing the bricks to relative humidity cycles inside the climatic chamber CLIMATS (Type EX2221-HA) while simultaneously recording their mass change using a scale with a resolution of 0.01 grams. Five relative humidity cycles were carried out at a constant temperature of $23{ }^{\circ} \mathrm{C}$ between the two relative humidity levels of $75 \%$ and $53 \%$, with each level maintained for 12 hours. This was sufficient to achieve steady state conditions corresponding to the attainment of a "stable cycle" where moisture uptake at the higher humidity of $75 \%$ is identical to moisture release at the lower humidity of 53\%. In all tests performed in the present work, the last three cycles were classified as stable cycles. Results from the above test are presented in terms moisture adsorption, which is ratio between the mass change $\Delta m$ (in grams) divided by the exposed sample surface, $S$ (in $\mathrm{m}^{2}$ ).

Figure 2 shows the maximum moisture adsorption, measured during the last stable cycle, of Proctor compacted, hypercompacted and extruded bricks quickly fired at different temperatures. Inspection of Figure 2 indicates that Proctor compacted bricks exhibit slightly higher moisture adsorption capacity compared to hypercompacted and extruded bricks at all firing temperatures. This is justified by the larger porosity of Proctor compacted bricks, which facilitates the exchange of water vapour with the surrounding atmosphere.

Inspection of Figure 2 also indicates that the moisture adsorption capacity drastically reduces, for all manufacturing methods, as firing temperature increases. This is due to both the progressive vitrification of the brick surface, which reduces the permeability to vapour, and the progressive disappearance of the finest pore fraction (Bruno et al., 2018). Finally, Figure 2 also shows that, at the highest temperature of $1000{ }^{\circ} \mathrm{C}$, the moisture adsorption capacity of the material becomes almost negligible. This indicates that the innate ability of raw earth to buffer moisture almost disappears as the firing temperature approaches the levels imposed during the manufacture of commercial fired bricks. 


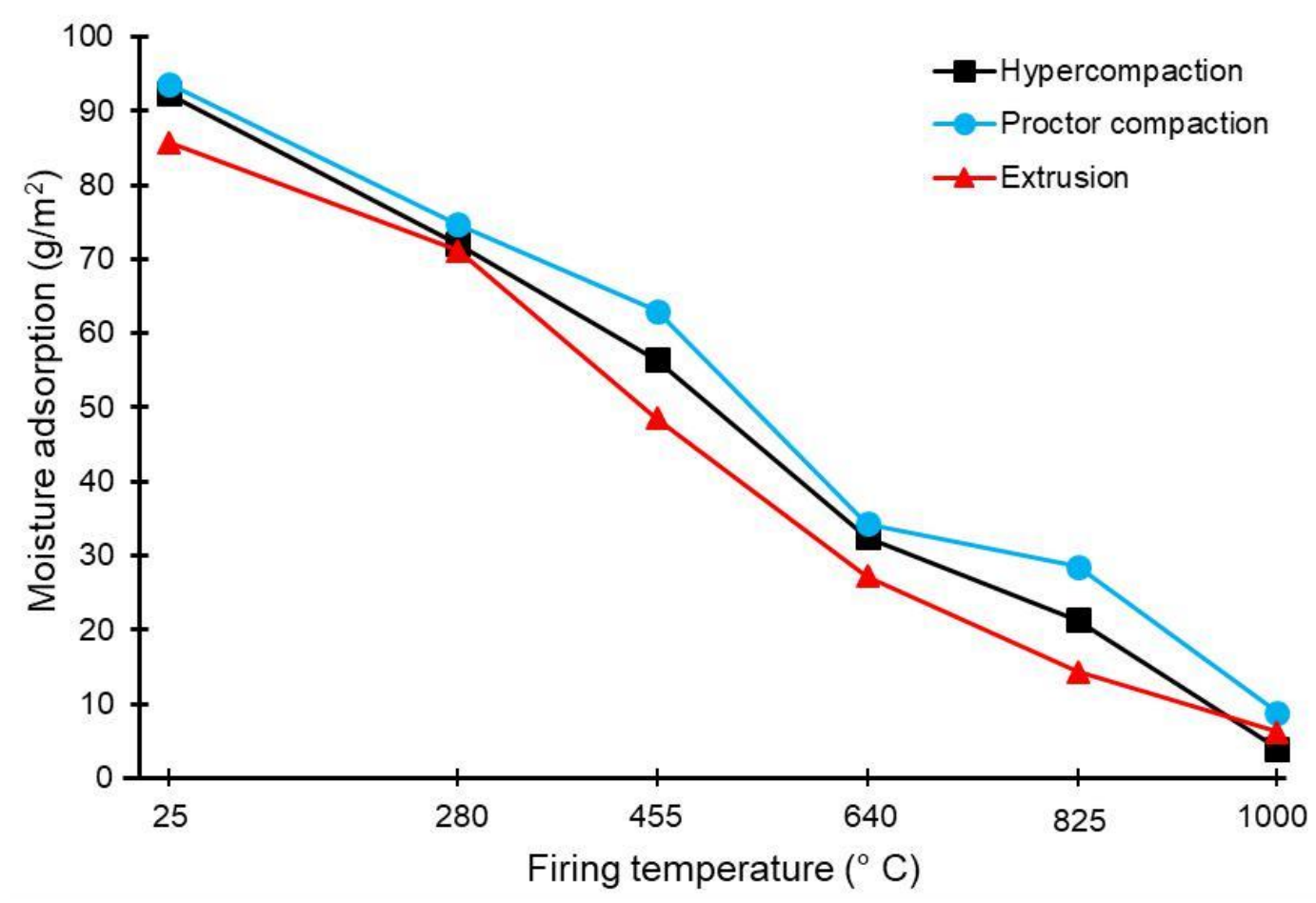

Figure 2. Moisture adsorption of unfired $\left(25^{\circ} \mathrm{C}\right)$ and quickly fired $(280,455,640$, $\left.825,1000{ }^{\circ} \mathrm{C}\right)$ bricks

according to ISO 24353 (2008).

\section{CONCLUSIONS}

This paper has presented an innovative and energy-efficient thermo-mechanical process for the manufacture of earth bricks. A series of laboratory tests was performed to assess compressive strength and moisture adsorption capacity of extruded, Proctor compacted and hypercompacted bricks quickly fired at five different temperatures of $280,455,640,825$ and $1000{ }^{\circ} \mathrm{C}$. The main outcomes of the research can be summarised as follows:

- Material strength depends on the manufacturing method with hypercompacted bricks exhibiting the highest strength at all firing temperatures followed by extruded bricks and finally Proctor compacted bricks. This result indicates a direct link between earth densification prior to firing and material strength.

- The highest strength is always attained at the intermediate firing temperature of 825 ${ }^{\circ} \mathrm{C}$, rather than at the highest one of $1000{ }^{\circ} \mathrm{C}$. This is a consequence of the fast thermal ramp that is imposed to the earth during quick firing. The highest strength is equal to 6.7 $\mathrm{MPa}$ for Proctor compacted bricks, 19.3 MPa for extruded bricks and $53 \mathrm{MPa}$ for hypercompacted bricks. This last value is comparable to that of top performing construction materials such as high-strength concretes.

- Moisture adsorption capacity reduces with growing firing temperature in a similar fashion for all manufacturing methods. Bricks fired at a temperature of $1000{ }^{\circ} \mathrm{C}$ (i.e. a temperature similar to that imposed during production of commercial bricks) exhibit almost no ability to exchange vapour with the surrounding environment. 
The above preliminary results suggest that brickwork factories can improve production quality while significantly reducing manufacturing time, energy consumption and environmental impact. Additional experimental evidence is however necessary to validate the proposed thermo-mechanical brick production process before implementing it at the industrial scale.

\section{ACKNOWLEDGEMENTS}

The financial contribution of the "Agglomération Côte Basque Adour" through the project "Performances hygrothermiques et durabilité de briques de terre crue pour l'écoconstruction" is gratefully acknowledged.

\section{REFERENCES}

AFNOR (1992). NF P 94-057. Soils: investigation and testing - Granulometric analysis - Hydrometer method.

AFNOR (1993). NF P 94-051; Soils: Investigation and testing - Determination of Atterberg's limits - Liquid limit test using Casagrande apparatus - Plastic limit test on rolled thread.

AFNOR (1995). XP P 94-041. Soils: investigation and testing - Granulometric description - Wet sieving method.

AFNOR (1999). NF P 94-093. Soils : Investigation and testing Determination of the compaction characteristics of a soil - Standard Proctor test Modified Proctor test.

AFNOR (2001). XP P13-901; Compressed earth blocks for walls and partitions: definitions - Specifications - Test methods - Delivery acceptance conditions.

Allinson, D., \& Hall, M. (2010). Hygrothermal analysis of a stabilised rammed earth test building in the UK. Energy and Buildings, 42(6), 845-852.

Aras, A. (2004). The change of phase composition in kaolinite-and illite-rich clay-based ceramic bodies. Applied Clay Science, 24(3-4), 257-269.

Arrigoni, A., Grillet, A. C., Pelosato, R., Dotelli, G., Beckett, C. T., Woloszyn, M., \& Ciancio, D. (2017).Reduction of rammed earth's hygroscopic performance under stabilisation: an experimental nvestigation. Building and

Environment, 115, 358-367.

ASTM C62-13a (2013). Standard Specification for Building Brick (Solid Masonry Units Made From Clay or Shale), ASTM International, West Conshohocken, PA, 2013. 
Baccour, H., Medhioub, M., Jamoussi, F., \& Mhiri, T. (2009). Influence of firing temperature on the ceramic properties of Triassic clays from Tunisia. Journal of materials processing technology, 209(6), 2812-2817.

Bruno, A.W. (2016). Hygro-mechanical characterisation of hypercompacted earth for building construction. PhD Thesis.

Bruno, A. W., Gallipoli, D., Perlot, C., \& Mendes, J. (2017). Mechanical behaviour of hypercompacted earth for building construction. Materials and Structures, 50(2), 160.

Bruno, A. W., Perlot, C., Mendes, J., \& Gallipoli, D. (2018). A microstructural insight into the hygro-mechanical behaviour of a stabilised hypercompacted earth. Materials and Structures, 51(1), 32.

CRATerre-EAG (1998). CDI, Compressed earth blocks: Standards - Technology series No.11. Brussels: CDI.

Dao, K., Ouedraogo, M., Millogo, Y., Aubert, J. E., \& Gomina, M. (2018). Thermal, hydric and mechanical behaviours of adobes stabilized with cement. Construction and Building Materials, 158, 84-96.

Gallipoli, D., Bruno, A. W., Perlot, C., \& Mendes, J. (2017). A geotechnical perspective of raw earth building. Acta Geotechnica, 12(3), 463-478.

Guettala, A., Abibsi, A., \& Houari, H. (2006). Durability study of stabilized earth concrete under both laboratory and climatic conditions exposure. Construction and Building Materials, 20(3), 119-127.

Houben, H., \& Guillaud, H. (1989). Traité de construction en terre. Editions Parenthèses.

Houben, H., \& Guillaud, H. (1994). Earth construction: a comprehensive guide. Intermediate Technology Publications.

ISO 24353 (2008). Hygrothermal performance of building materials and products determination of moisture adsorption/desorption properties in response to humidity variation. Geneva, Switzerland: International Organization for Standardization.

Jayasinghe, C., \& Kamaladasa, N. (2007). Compressive strength characteristics of cement stabilized rammed earth walls. Construction and Building Materials, 21(11), 1971-1976.

Jordán, M. M., Boix, A., Sanfeliu, T., \& De la Fuente, C. (1999). Firing transformations of cretaceous clays used in the manufacturing of ceramic tiles. Applied Clay Science, 14(4), 225-234.

Karaman, S., Ersahin, S., \& Gunal, H. (2006). Firing temperature and firing time influence on mechanical and physical properties of clay bricks. Journal of Scientific \& Industrial Research, 65(2), 153-159. 
Kariyawasam, K. K. G. K. D., \& Jayasinghe, C. (2016). Cement stabilized rammed earth as a sustainable construction material. Construction and Building Materials, $105,519-527$.

Little, B., \& Morton, T. (2001). Building with earth in Scotland: Innovative design and sustainability. Edinburgh: Scottish Executive Central Research Unit.

Liuzzi, S., Hall, M. R., Stefanizzi, P., \& Casey, S. P. (2013). Hygrothermal behaviour and relative humidity buffering of unfired and hydrated lime-stabilised clay composites in a Mediterranean climate. Building and Environment, 61, 82-92.

Mbumbia, L., de Wilmars, A. M., \& Tirlocq, J. (2000). Performance characteristics of lateritic soil bricks fired at low temperatures: a case study of Cameroon. Construction and Building Materials, 14(3), 121-131.

McGregor, F., Heath, A., Fodde, E., \& Shea, A. (2014). Conditions affecting the moisture buffering measurement performed on compressed earth blocks. Building and Environment, 75, 11-18.

MOPT (1992). Bases Para el Diseño y Construcción con Tapial. Madrid, Spain: Centro de Publicaciones, Secretaría General Técnica, Ministerio de Obras Públicas y Transportes. 
Morel, J. C., Mesbah, A., Oggero, M., \& Walker, P. (2001). Building houses with local materials: means to drastically reduce the environmental impact of construction. Building and Environment, 36(10), 1119-1126.

Pacheco-Torgal, F., \& Jalali, S. (2012). Earth construction: Lessons from the past for future eco-efficient construction. Construction and building materials, 29, 512-519.

Soudani, L., Fabbri, A., Morel, J. C., Woloszyn, M., Chabriac, P. A., Wong, H., \& Grillet, A. C. (2016). Assessment of the validity of some common assumptions in hygrothermal modelling of earth based materials. Energy and Buildings, 116, 498511.

Soudani, L., Woloszyn, M., Fabbri, A., Morel, J. C., \& Grillet, A. C. (2017). Energy evaluation of rammed earth walls using long term in-situ measurements. Solar Energy, 141, 70-80.

Venkatarama Reddy, B. V., Suresh, V., \& Nanjunda Rao, K. S. (2016). Characteristic Compressive Strength of Cement-Stabilized Rammed Earth. Journal of Materials in Civil Engineering, 04016203.

Walker, P., \& Stace, T. (1997). Properties of some cement stabilised compressed earth blocks and mortars. Materials and structures, 30(9), 545-551.

West, R. R., \& Gray, T. J. (1958). Reactions in Silica-Alumina Mixtures. Journal of the American Ceramic Society, 41(4), 132-136.

Worrell, E., Price, L., Martin, N., Hendriks, C., \& Meida, L. O. (2001). Carbon dioxide emissions from the global cement industry. Annual review of energy and the environment, 26(1), 303-329. 
